\title{
Badger density and distribution of setts in Białowieża Primeval Forest (Poland and Belarus) compared to other Eurasian populations
}

\author{
Rafał KOWALCZYK, Aleksei N. BUNEVICH and Bogumiła JĘDRZEJEWSKA
}

Kowalczyk R., Bunevich A. N. and Jędrzejewska B. 2000. Badger density and distribution of setts in Białowieża Primeval Forest (Poland and Belarus) compared to other Eurasian populations. Acta Theriologica 45: 395-408.

Distribution and occupancy of setts by badgers Meles meles (Linnaeus, 1758) were surveyed in Białowieża Primeval Forest $\left(1450 \mathrm{~km}^{2}\right)$, one of the best preserved temperate lowland forests in Europe, in 1946-1961 and 1979-1999. In the Belarussian part of BPF in 1946-1951, badger density was estimated as 0.33 setts and 1.27 individuals $/ 10 \mathrm{~km}^{2}$. After predator control in the late $1950 \mathrm{~s}$, the number of active setts decreased to $0.09 / 10$ $\mathrm{km}^{2}$ in 1961. Since the 1970s, badger population has been recovering; in 1979-1999, it averaged 0.16 setts and $0.61 \mathrm{ind} / 10 \mathrm{~km}^{2}$. In the Polish part of BPF, where badgers were not hunted, the densities in 1996-1999 were estimated as 0.41 setts and 1.57 ind $/ 10$ $\mathrm{km}^{2}$. In the whole BPF, badger main setts were spaced regularly, with the nearest neighbour distance between active setts varying from 2.2 to $13.3 \mathrm{~km}$ (mean $=5.3 \mathrm{~km}$, $\mathrm{SD}=2.1$ ). Surveys of 21 main setts during 1979-1999 (totally 171 sett-years) revealed that badgers occupied the setts in $68.4 \%$ of cases, raccoon dogs Nyctereutes procyonoides in $12.9 \%$, and red foxes Vulpes vulpes in $7 \%$. Joint utilisation of the same setts by badgers and raccoon dogs was recorded in $5.3 \%$ of cases.

Reviewing the literature on badger densities in 35 localities in the Palaeartic region showed that badgers attained rather high densities on the British Isles (14.9 setts/10 $\mathrm{km}^{2}$, range 1.1-45.5; and $93.8 \mathrm{ind} / 10 \mathrm{~km}^{2}$, range 8.6-307.0) compared to continental Eurasia (1.7 setts $/ 10 \mathrm{~km}^{2}$, range $0.4-6.5$; and $6.3 \mathrm{ind} / 10 \mathrm{~km}^{2}$, range $1.6-15.2$ ). The number of badgers inhabiting a sett increased with log density of setts. Densities of badger setts did not depend on latitude but were negatively correlated with forest cover $\left(R^{2}=0.22, p=0.008\right)$. We proposed that the biological mechanism behind this relationship was the higher biomass and availability of earthworms in open pastures and grasslands than in forests.

Mammal Research Institute, Polish Academy of Sciences, 17-230 Białowieża, Poland, e-mail: rkowal@bison.zbs.bialowieza.pl (RK, BJ); State National Park Belovezhskaya Pushcha, Brest Oblast, Kamenec Raion, 225063 Kamenyuki, Belarus Republic (ANB)

Key-words: Meles meles, population density, sett occupancy, geographic variation, forest cover, Palaeartic region

\section{Introduction}

The Eurasian badger Meles meles (Linnaeus, 1758) is widely distributed throughout the Palearctic region (Neal 1986). Badgers live in groups and occupy urderground setts, used for reproduction, winter sleep, and daily shelters 
throughout the year. Data on sett occupancy, distribution, and badger group size give an indicator of badger population status and, if collected for longer periods, approximate the trends in badger numbers (eg Wiertz and Vink 1986, Thornton 1988). In western Europe, where natural forested habitats are rare, badgers have adapted to environments influenced by man (such as pastures) and occur in high densities (eg 75 individuals $/ 10 \mathrm{~km}^{2}$, Harris and Cresswell 1987; $253 \mathrm{ind} / 10 \mathrm{~km}^{2}$, Rogers et al. 1997). In central and eastern Europe, badgers are usually forest-dwellers and their densities seem generally lower (eg Likhachev 1956, Goszczyński 1999).

In this study, we present and analyse the data on the distribution and occupancy of badger setts in the pristine temperate woodland of Białowieża (E Poland and W Belarus) in years 1946-1961 and 1979-1999. Based on observations of badger group sizes, we calculated the density of Białowieża's population and compared it with other Eurasian localities.

\section{Study area}

Białowieża Primeval Forest (=BPF, $\left.52^{\circ} 30^{\prime}-53^{\circ} \mathrm{N}, 23^{\circ} 30^{\prime}-24^{\circ} 15^{\prime} \mathrm{E}\right)$, located on the Polish-Belarussian border, is the best preserved woodland in lowland temperate Europe. It lies in the boreal nemoral zone and covers the area of $1450 \mathrm{~km}^{2}\left(580 \mathrm{~km}^{2}\right.$ in Poland and $870 \mathrm{~km}^{2}$ in the Belarus Republic). In the Polish part of BPF, coniferous and mixed tree stands dominated by pine Pinus silvestris and spruce Picea abies cover 52\% of the area, rich deciduous stand dominated by oak Quercus robur, hornbeam Carpinus betulus, and lime Tilia cordata 16\%, and wet forests of alder Alnus glutinosa and ash Fraxinus excelsior 20\%. Birch Betula verrucosa and B. pubescens and aspen Populus tremula stands cover $12 \%$ of the area. The Polish part includes the protected forests of Bialowieża National Park ( $100 \mathrm{~km}^{2}$, with tree stands of an average age exceeding 100 years), and exploited forests managed by State Forestry ( $480 \mathrm{~km}^{2}$, average age 72 years). The latter are exploited by small clearcuts and replantation.

The Belarussian part of BPF has the status of State National Park. Exploitation of timber is small and selective (dead and dying trees only, no clearcuts). Tree stands are dominated by coniferous pine and mixed forests, $69 \%$ of the area. Oak-lime-hornbeam forests cover $6 \%$, wet alder-ash forests $16 \%$, and stands dominated by birch and aspen $9 \%$. The average age of tree stands is 100 years.

The altitude of BPF varies from 134 to $202 \mathrm{~m}$ a.s.l. The relief of area is generally flat, in some places with smoothly rising hills and shallow depressions. Soils were formed mainly by glacial sediments. Brown earth soils occur mainly under broad-leaved forests, podzol earth soils under mixed and coniferous forests, whereas gley, peat, and bog earth soils occur under wet forests. Water table level varies from 5-15 m below ground level in mixed and dry coniferous forests, to 1-5 $\mathrm{m}$ in deciduous forests and $0.2-1 \mathrm{~m}$ in wet habitats.

The climate of BPF is transitional between Atlantic and continental types, with clearly marked cold and warm seasons. The mean annual temperature is $6.8^{\circ} \mathrm{C}$. The coldest month is January (mean daily temperature $\left.-4.7^{\circ} \mathrm{C}\right)$, and the warmest is July $\left(17.8^{\circ} \mathrm{C}\right)$. Snow cover lasts for an average of 92 days per year. More information on the habitats and abiotic conditions of BPF is given by Faliński (1986), Kwiatkowski (1994), and Jędrzejewska and Jędrzejewski (1998).

BPF harbours a rich community of predators with three species of medium-sized carnivores utilising the burrows: the badger, the red fox Vulpes vulpes, and the raccoon dog Nyctereutes procyonoides. Raccoon dogs were introduced to the former Soviet Union from their original distribution area in Far East, and colonised BPF in the early 1950s (Bunevich and Dackevich 1985). 


\section{Material and methods}

In the Belarussian part of BPF, data on the localisation, number, and occupation of badger setts were collected by game wardens and forestry personnel in 1946-1961, and were archived by the Game Management Department of the Hunting Preserve Belovezhskaya Pushcha (before 1958: Belovezhskaya Pushcha Reserve). Annual survey of burrows and setts was resumed in 1979 and was conducted in 1979-1989 and 1993-1995 by game and forestry personnel under the supervision of A. N. Bunevich. In the Polish part of BPF no data were available prior to 1986. Since 1986, badger setts were searched for and inspected only in the Białowieża National Park $\left(50 \mathrm{~km}^{2}\right)$. In 1996-1999, the survey was intensified to cover a major portion of the Polish part of BPF (data collected by R. Kowalczyk, W. Jędrzejewski, and B. Jędrzejewska).

All setts were surveyed in spring and inspected at irregular intervals year round. During the survey the status of a burrow (active or nonactive) was noted and the species of carnivore occupying it was identified by tracks, signs of burrow cleaning, paths, direct observations of animals, and any other signs of activity. Setts were clasified as main badger setts based mainly on evidence of use (Thornton 1988). Localities of main setts were plotted on a map and the nearest neighbour distances were measured as the shortest straight-line distance between the closest occupied setts. Six badger groups alternately utilised two setts located close to each other $(<1.5 \mathrm{~km})$. In those cases, the sett used more frequently was always taken for NND measurements. Type of habitat (river valley, bog forests, and drier deciduous, mixed or coniferous forests) separating setts was recorded on the basis of forestry maps.

Number of badgers inhabiting a sett was estimated by spring and summer observations at the setts. In 1947-1958, observations were done in the Belarussian part of BPF ( 6 records from 4 setts, including one sett observed in 3 years). In 1996-1999 in the Polish part, observations were conducted at 6 setts ( 1 to 4 years each, totally 14 records).

\section{Results}

Of 57 burrows surveyed in the Belarussian part of BPF in 1946-1951, 29 were classified as main badger setts, which yielded a density of 0.33 setts $/ 10 \mathrm{~km}^{2}$ (Fig. 1). As the mean number of badgers (adults and young) inhabiting a sett was 3.8 ( $\mathrm{SE}=$ 0.31 , range $3-5, n=6$ ), we can estimate that the density of badgers in the Belarussian part of the Forest in 1946-1951 approximated $1.27 \mathrm{ind} / 10 \mathrm{~km}^{2}$. The setts were distributed rather regularly over the woodland area (Fig. 2). The nearest neighbour distance (NND) between occupied setts varied from 2.8 to $9.3 \mathrm{~km}$, mean $4.9 \mathrm{~km}(\mathrm{SD}=1.7)$ (Fig. 3). Based on the mean NND and having assumed no significant overlap among territories of badger families inhabiting different setts, we roughly estimated that each group of badgers utilised, on average, $18 \mathrm{~km}^{2}$ of the woodland.

In 1958, heavy control of medium-sized carnivores began in the Belarussian part of BPF. The target pests were red foxes, raccoon dogs, and polecats Mustela putorius (Korochkina et al. 1980, see also Jędrzejewska and Jędrzejewski 1998), but badgers also suffered, because one of the methods of predator control was destruction, by digging, of breeding dens in spring and summer. Rusanov (1962) reported that in 1961 alone, 40 burrows of medium-sized carnivores were destroyed. In effect, by 1961 , the number of active main setts of badgers decreased to 8 , which 


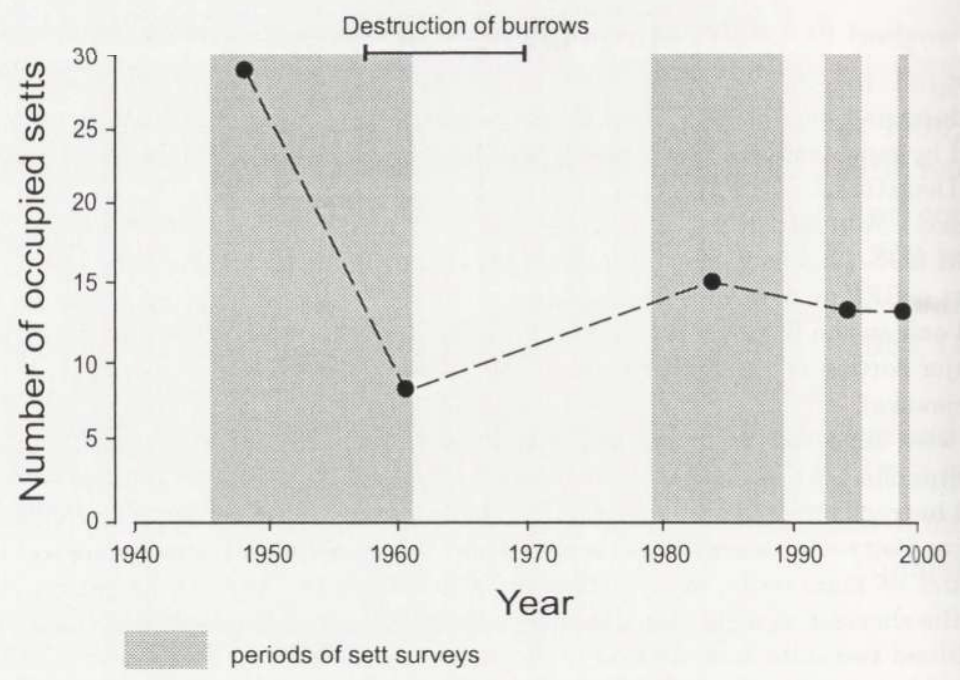

Fig. 1. Changes in numbers of occupied badger setts in the Belarussian part of Białowieża Primeval Forest $\left(870 \mathrm{~km}^{2}\right)$ in $1946-1999$. Black points are averaged values for the following periods: 1946-1951, 1979-1989, 1993-1995, and annual values for 1961 and 1999.

was equivalent to the density of $0.09 \mathrm{setts} / 10 \mathrm{~km}^{2}$ and thus only 0.35 badgers $/ 10$ $\mathrm{km}^{2}$.

The persecution of foxes, raccoon dogs, and polecats (and the resultant destruction of badger setts as well) ended in 1970. Despite some recorded poaching of badgers (for pelts and fat as folk medicine) their population slowly recovered after 1970. In 1978, hunting for badgers was prohibited in the Belarussian part of BPF, and in 1981 the badger was included into the Red Data Book of Belarus as a rare species.

From 1979-1989, of 308 burrows surveyed regularly in the Belarussian part of BPF, 15 setts were found occupied by badgers. During surveys in 1993-1995 and 1999, 131 burrows and setts were checked, and badgers were found in 13 setts (Figs 1 and 2). Only 6 of 29 setts occupied in 1946-1951 (ie 21\%) were still active in 1999. In effect, 25 years after the persecution had ceased, badgers recovered to only half of their numbers recorded before 1950. From 1979-1999, the density of badger population in the Belarussian part of BPF averaged 0.16 setts and $0.61 \mathrm{ind} / 10 \mathrm{~km}^{2}$. The NND's between occupied setts ranged from 2.2 to $13.3 \mathrm{~km}$, averaging $6.4 \mathrm{~km}$ $(\mathrm{SD}=3.0)$ (Fig. 3).

In the Polish part of BPF, the hunting harvest of badgers (which are game animals) was very small in the 1970 s and it has ceased completely after 1984 (L. Miłkowski, unpubl.). However, some poaching might have occurred. In 1996-1999, a total of 78 burrows were surveyed in the area of $290 \mathrm{~km}^{2}$, and 12 main badger setts were found (Fig. 2). The mean number of badgers inhabiting a sett was 3.8 (SE $=0.38$, range $2-6, n=14$ ). The estimated density was 0.41 setts $/ 10 \mathrm{~km}^{2}$ and 1.57 

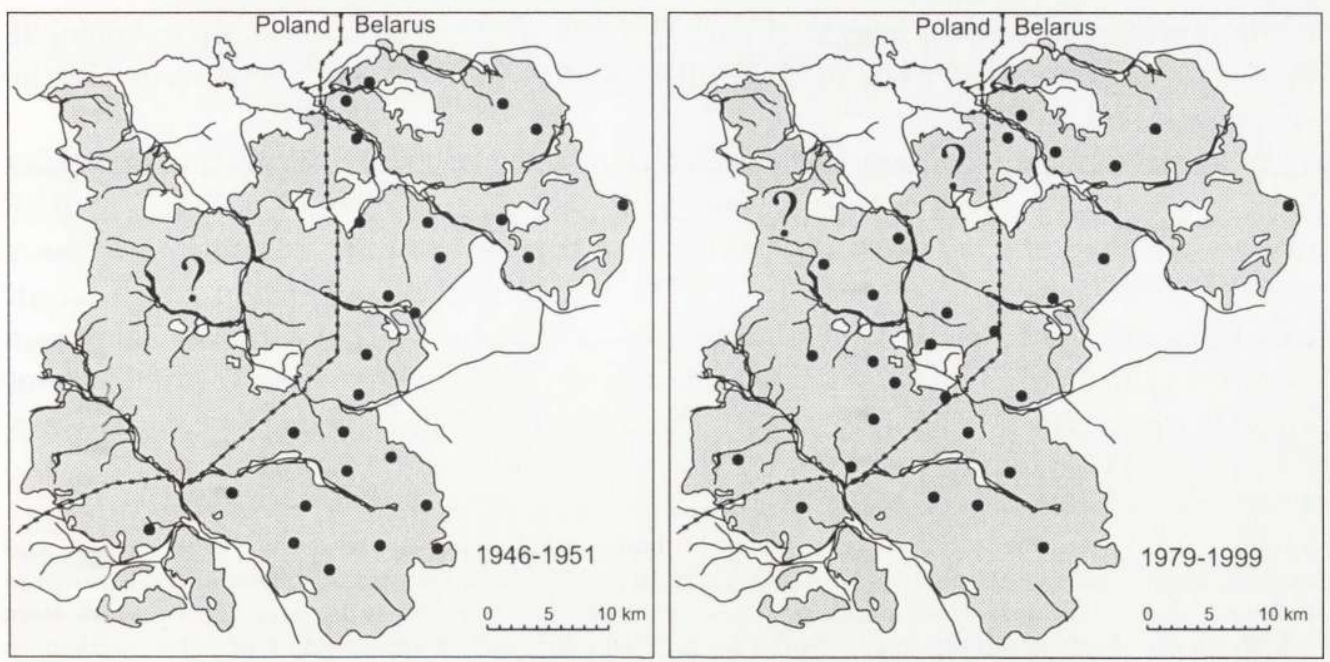

Fig. 2. Distribution of main badger setts (black dots) in BPF in the past (the Belarussian part only, 1946-1951) and recent years (Belarussian part, 1979-1999; Polish part, 1985-1999). ? - no data. Shaded area denotes woodland.

ind $/ 10 \mathrm{~km}^{2}$. The NND's between active setts ranged from 2.6 to $6.0 \mathrm{~km}$, on average $4.7 \mathrm{~km}(\mathrm{SD}=1.1)$ (Fig. 3$)$.

Based on the surveys done in the 1990s, the mean densities of badger population in the whole Forest (data available for $1160 \mathrm{~km}^{2}$ ) were estimated as $0.22 \mathrm{setts} / 10$ $\mathrm{km}^{2}$, vhich was equivalent to $0.82 \mathrm{ind} / 10 \mathrm{~km}^{2}$. The mean NND between active setts estimated for the whole BPF was $5.3 \mathrm{~km}$ ( $\mathrm{SD}=2.1$, range 2.2-13.3) (Fig. 3). Based on the mean NND's and assuming no significant overlap among territories, we

$1946-1951$

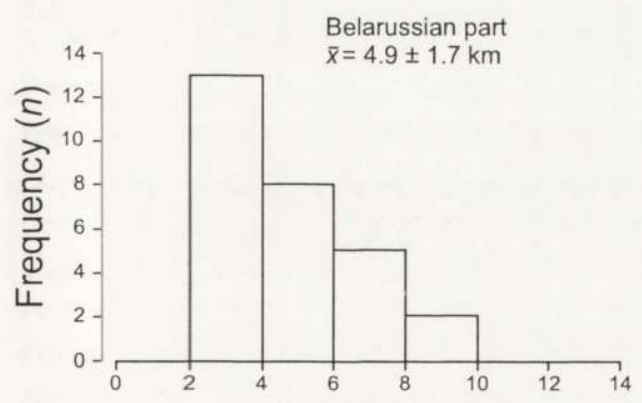

1979-1999

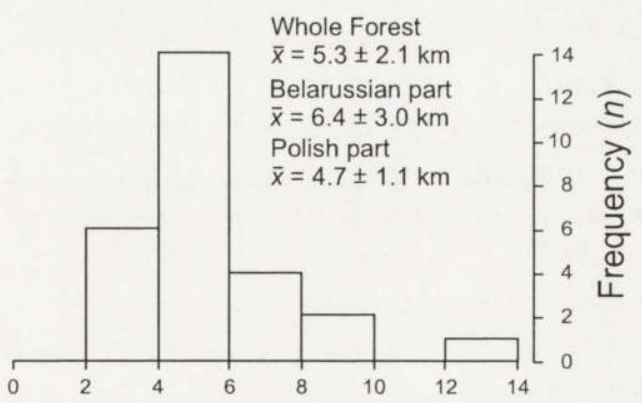

Nearest neighbour distance $(\mathrm{km})$

Fig. 3. Frequency distributions and mean values $( \pm$ SD) of nearest neighbour distances among occupied main setts of badgers in BPF. Data as in Fig. 2. 
estimated that a group of badgers living in a sett could have utilised, on average, 22 $\mathrm{km}^{2}$, this area being smaller in the Polish part of BPF $\left(17 \mathrm{~km}^{2}\right)$ and larger in the Belarussian part $\left(32 \mathrm{~km}^{2}\right)$.

No significant differences were detected in the frequency distribution of NND's between setts surveyed in the various time periods and in the two parts of BPF (Mann-Whitney $U$-test: $U_{\mathrm{s}}$ from 104 to $265, p$ from 0.1 to 0.9 ). Furthermore, there were no significant differences in NND's between setts separated by different habitats, although there was a tendency of larger NND's with an increased bogginess of the area. Setts separated by marshy river valleys were located farther apart (average NND $=5.9 \mathrm{~km}, n=10$ ) than those separated by bog forests (mean =

Table 1. Occupation of 21 main badger setts by badgers Meles meles, red foxes Vulpes vulpes, and raccoon dogs Nyctereutes procyonoides in the years 1979-1999 in the Belarussian part of the Białowieza Primeval Forest. If badgers and raccoon dogs occupied a sett in the same year, percentages were calculated for both species together (in brackets) and for each species. Pairs of setts marked in superscripts by the same letters $\left({ }^{\mathrm{a}-\mathrm{a}}\right.$ to $\left.{ }^{\mathrm{f}-\mathrm{f}}\right)$ were located in one territory of badgers.

\begin{tabular}{|c|c|c|c|c|c|c|}
\hline \multirow[t]{2}{*}{ Sett no. } & \multirow{2}{*}{$\begin{array}{c}n \text { years } \\
\text { surveyed }\end{array}$} & \multicolumn{4}{|c|}{$n$ years the sett was occupied by: } & \multirow{2}{*}{$\begin{array}{c}n \text { years } \\
\text { nonactive }\end{array}$} \\
\hline & & Badger & Raccoon dog & $\begin{array}{l}\text { (Badger and } \\
\text { raccoon dog } \\
\text { together) }\end{array}$ & Red fox & \\
\hline $1^{\mathrm{a}}$ & 15 & 12 & 2 & (2) & 1 & 2 \\
\hline $2^{a}$ & 11 & 3 & 2 & (1) & 3 & 4 \\
\hline 3 & 14 & 4 & 3 & - & 1 & 6 \\
\hline 4 & 13 & 9 & - & - & 1 & 3 \\
\hline $5^{\mathrm{b}}$ & 12 & 9 & - & - & 2 & 1 \\
\hline $6^{\mathrm{b}}$ & 9 & 5 & 2 & - & - & 2 \\
\hline 7 & 13 & 13 & 2 & (2) & - & - \\
\hline $8^{c}$ & 12 & 7 & - & - & 1 & 4 \\
\hline $9^{c}$ & 2 & 2 & - & - & - & - \\
\hline 10 & 10 & 10 & - & - & - & - \\
\hline $11^{d}$ & 10 & 10 & 1 & (1) & - & - \\
\hline $12^{\mathrm{d}}$ & 5 & 3 & 2 & (1) & 1 & - \\
\hline $13^{e}$ & 10 & 6 & 2 & - & - & 2 \\
\hline $14^{e}$ & 7 & 4 & 1 & - & - & 2 \\
\hline 15 & 7 & 4 & - & - & 1 & 2 \\
\hline $16^{f}$ & 8 & 4 & 3 & - & 1 & - \\
\hline $17^{\mathrm{f}}$ & 1 & 1 & - & - & - & - \\
\hline 18 & 6 & 6 & 2 & (2) & - & - \\
\hline 19 & 3 & 2 & - & - & - & 1 \\
\hline 20 & 2 & 2 & - & - & - & - \\
\hline 21 & 1 & 1 & - & - & - & - \\
\hline Total $n$ & 171 & 117 & 22 & (9) & 12 & 29 \\
\hline Percentage & 100 & 68.4 & 12.9 & (5.3) & 7.0 & 17.0 \\
\hline
\end{tabular}


$5.1 \mathrm{~km}, n=7$ ), and the drier deciduous, mixed, and coniferous forests (mean NND $=4.8 \mathrm{~km}, n=9$ ).

In 1979-1999, the occupancy of 21 main setts located in 15 territories of badgers was surveyed in the Belarussian part of BPF (Table 1). Each sett was checked annually for 1 to 15 years, on average 8 years (171 sett-years in total). Badgers occupied the setts in $68.4 \%$ of years. Also, two other species of carnivores were reported to inhabit the setts: raccoon dogs (12.9\% of cases) and foxes (7\%). They usually settled in nonactive setts for wintering and/or reproduction. However, joint utilisation of setts by badgers and raccoon dogs was observed in $5.3 \%$ of years. In $17 \%$ of cases, setts remained unoccupied (Table 1 ).

Also, we estimated the occupation rate of badger territories. In a total of 137 annual surveys, badgers were found occupying potential territories in 103 cases, ie $75.2 \%$ (in six territories badgers utilised two setts simultaneously or alternately in subsequent years). Of 16 territories surveyed for at least 5 years, only 4 were continuously occupied by badgers during the study period. Two territories became abandoned by badgers, one because of clear-cutting of the forest around it, and the second due to poaching (the sett was destroyed by digging). Utilisation of other setts was intermittent in time, with breaks (absence of badgers) lasting from 1 to 10 years.

\section{Discussion}

Badgers living in the Polish part of BPF in the 1990s and those in the Belarussian part in the late 1940s were not significantly disturbed by humans, so we think that $0.3-0.4 \mathrm{setts} / 10 \mathrm{~km}^{2}$ and $1.3-1.6$ badgers $/ 10 \mathrm{~km}^{2}$ are densities typical of well-preserved temperate forests in Central Europe. Based on nearest neighbour distances between active setts, we estimated that a typical badger territory would cover $17-18 \mathrm{~km}^{2}$. The radio-tracking studies conducted in the Polish part of BPF in 1997-1999 supported these estimates. Badger group territories ranged from 8 to 24 $\mathrm{km}^{2}$ (R. Kowalczyk, A. Zalewski, B. Jędrzejewska, and W. Jędrzejewski, unpubl.).

How do these densities compare to other populations of badgers from the Palearctic region? We reviewed the available data from 35 localities ranging from Ireland in the West to Kazakhstan in the East, and from Italy and Spain in the South to Norway and the Russian Karelia in the North (Appendix I). The reported densities of main setts varied enormously, from 0.4 sett $/ 10 \mathrm{~km}^{2}$ in Białowieża Forest (Poland) and Alto Manzanares (Spain) to over $20 \mathrm{setts} / 10 \mathrm{~km}^{2}$ in some regions of England and Ireland. Data from the British Isles and those from the continental Europe and Asia differed significantly (Fig. 4). In continental Eurasia, mean density of badger setts was 1.7 setts $/ 10 \mathrm{~km}^{2}$ ( $\mathrm{SD}=1.4$, range 0.4-6.5), whereas on the British Isles, it was 14.9 setts $/ 10 \mathrm{~km}^{2}$ ( $\mathrm{SD}=13.6$, range 1.1-45.5). Estimates of population density of badgers were available from 24 localities. Again, badgers in the British Isles attained significantly higher densities (mean $=93.8$ ind $/ 10 \mathrm{~km}^{2}, \mathrm{SD}=91.8$, range 8.6-307) than those in continental Eurasia (mean $=6.3$ 


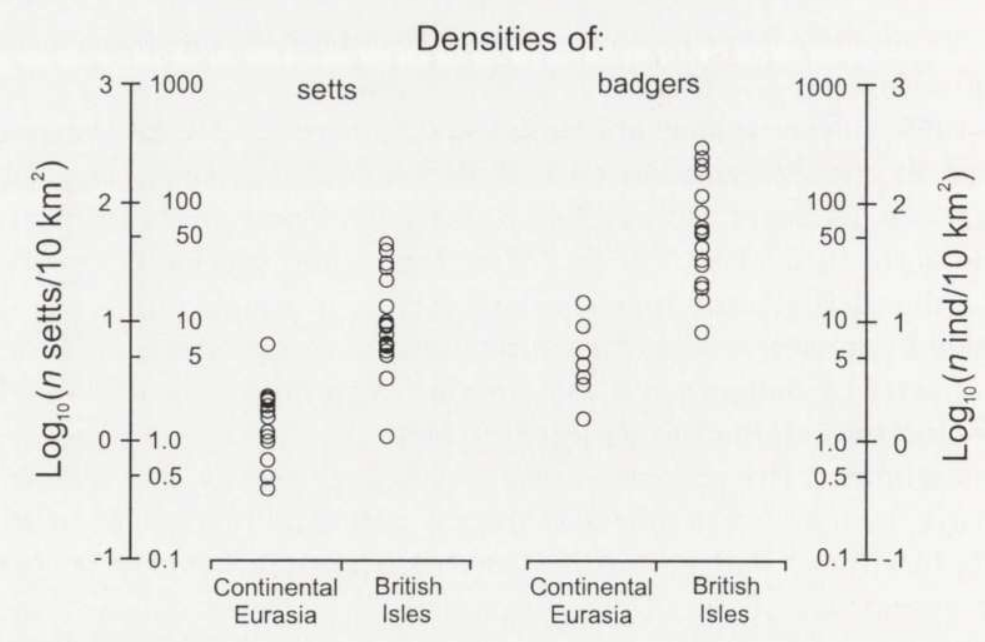

Fig. 4. Densities of badger setts (left panel) and population (right panel) in the Palaearctic region. Each point denotes one locality (list and sources of data in Appendix I). Badger densities in continental Eurasia and those on the British Isles differed significantly (setts: $U_{s}=274, p<0.0005$; badger population: $U_{s}=117, p<0.0005$; Mann-Whitney $U$-test).

ind $/ 10 \mathrm{~km}^{2}, \mathrm{SD}=4.7$, range $1.6-15.2$ ) (Fig. 4). In low density population, not only were the setts distributed sparsely, but also each sett was inhabited by a lower number of badgers ( $2-4 \mathrm{ind} / \mathrm{sett})$ than in high density populations $(6-10 \mathrm{ind} / \mathrm{sett})$ (Fig. 5).

The observed variation in badger sett density was not related to latitude $\left(R^{2}=\right.$ $0.002, p>0.8, n=34$ ). This suggests that the north-south gradient in temperature

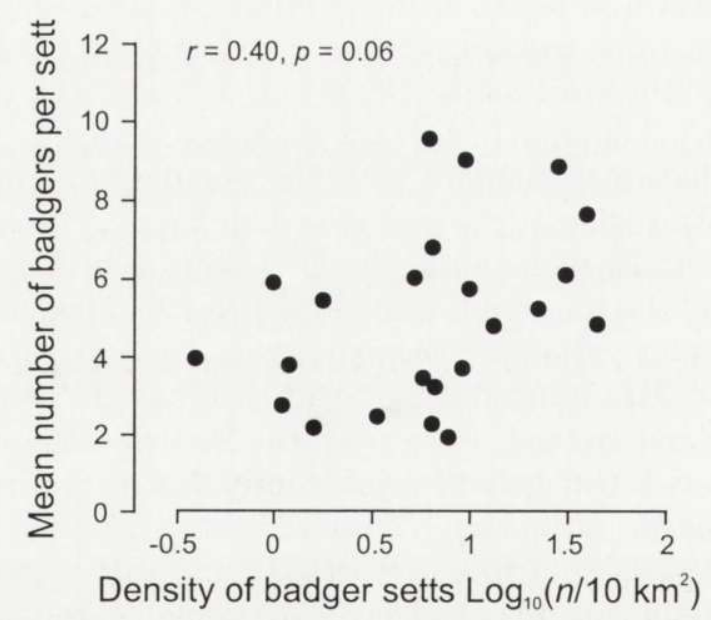

Fig. 5. Mean number of badgers in a group occupying one main sett in relation to the density of setts; data from 23 localities in Eurasia (list and sources of data in Appendix I). 


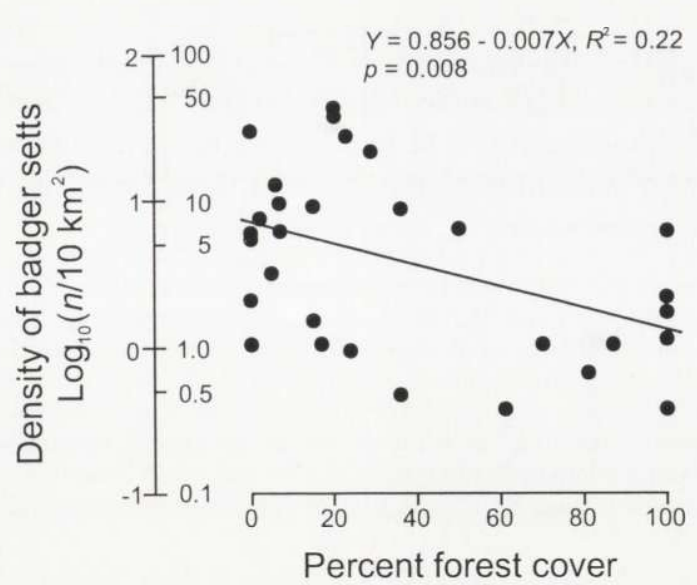

Fig. 6. Density of badger setts in relation to percent forest cover; data from 31 localities in Eurasia (list and sources of data in Appendix I).

and precipitation does not play a major role in shaping badger densities in the Palaearctic region, though latitude was an essential factor explaining biogeographical differences in badger diet composition (Goszczyński et al. 2000). Log densities of badger setts correlated negatively with the percent forest cover in the area (Fig. 6). Variation in wood cover explained, however, a fairly small portion $(22 \%)$ of the total variation in badger sett densities in Eurasia.

We propose that the most plausible biological mechanism behind this correlation is the supply and availability of earthworms, the most important food of badgers throughout the temperate and boreal zone (Goszczyński et al. 2000). Badgers avoid deforested land for sett localisation (Kruuk 1978, Feore and Montgomery 1999), but wherever available they utilise open fields and pastures as foraging grounds (eg Hofer 1988, Seiler et al. 1995). Kruuk and Parish (1982) reported that, in Great Britain, badger density showed a strong positive correlation with earthworm biomass for the given habitat. Different methods of earthworm censusing applied in various European countries make it difficult to conduct large-scale comparison of earthworm biomass. Nonetheless, studies on earthworms in various habitats in western Belarus, Norway, and Great Britain documented that pastures and grasslands were characterised by much bigger standing crops of worms than coniferous and mixed forests, and usually also higher than or comparable to deciduous forests (Utenkova and Nazarova 1968, Hofer 1988, Broseth et al. 1997).

We propose that another crucial factor in determining badger densities is the availability of earthworms to foraging badgers. Firstly, earthworm assemblages in European continental forests are dominated by Dendrobaena spp., a rather small-sized species compared to Lumbricus terrestris that dominate in pastures and meadows. Secondly, for badgers, foraging for worms may be easier in grazed pastures with low grass than on the forest floor covered with vegetation and dead 
litter. Kruuk et al. (1979) documented that increasing length of grass negatively affected the efficiency of badger foraging on earthworms. Thus, European badgers appeared to be a species that is not only adapted to anthropogenic transformation of woodlands into open grassland, pastures and field-forest mosaic, but one which also exploits the advantages this brings.

Acknowledgements: We thank the game wardens and foresters of the State National Park Belovezhskaya Pushcha (Kamenyuki, Belarus), who participated in badger sett surveys in 1946-95. We are grateful to the foresters in the Białowieża, Browsk, and Hajnówka forestry districts and the wardens of Białowieża National Park (Poland) for information on sett localisation. E. Bujko helped in badger sett surveys in the Polish part of BPF in 1996-1999. S. Roper (Southwest Ecological Surveys, UK), D. Knight (University of Southampton, UK), and the group of volunteers from England helped in observations of badgers. We are also grateful to Drs J. Goszczyński, H. Kruuk, and C. Newman for their reviews of the manuscript. The study was financed by the budget of the Mammal Research Institute PAS and the grant KBN 6 P04C 05712 .

\section{References}

Biancardi C. M. and Rinetti L. 1998. The distribution of badger (Meles meles L., 1758) setts in Northern Luino area (Varese county, Lombardy, Italy) (Mammalia, Mustelidae). Atti dela Societa italiana di Scienze naturali e del Museo civile di Storia naturale, Milano 139(1): 57-64. [In Italian with English summary]

Broseth H., Knutsen B. and Bevanger K. 1997. Spatial organization and habitat utilisation of badgers Meles meles: effects of food patch dispersion in the boreal forest of central Norway. Zeitschrift für Säugetierkunde 62: 12-22.

Bunevich A. N. and Dackevich V. A. 1985. [Spatial distribution and food of the raccoon dog in Belovezha Primeval Forest]. Zapovedniki Belorussii, Issledovaniya 9: 114-129. [In Russian]

Cheeseman C. L., Jones G. W., Gallagher J. and Mallinson P. J. 1981. The population structure, density and prevalence of tuberculosis (Mycobacterium bovis) in badgers (Meles meles) from four areas in south-west England. Journal of Applied Ecology 18: 795-804.

Cheeseman C. L., Little T. W. A., Mallinson P. J., Page R. J. C., Wilesmith J. W. and Pritchard D. G. 1985. Population ecology and prevalence of tuberculosis in badgers in an area of Staffordshire. Mammal Review 15: 125-135.

Cresswell W. J. and Harris S. 198:8. Foraging behaviour and home range utilization in a suburban badger (Meles meles) population. Mammal Review 18: 37-49.

Faliński J. B. 1986. Vegetation dynamics in temperate lowland primeval forest. Dr W. Junk Publishers, Dordrecht: $1-537$.

Feore S. and Montgomery W. I. 19:99. Habitat effects on the spatial ecology of the European badger (Meles meles). Journal of Zoology, London 247: 537-549.

Goszczyński J. 1999. Fox, raccoon dog and badger densities in North Eastern Poland. Acta Theriologica 44: 413-420.

Goszczyński J., Jędrzejewska B. and Jędrzejewski W. 2000. Diet composition of badgers (Meles meles) in a pristine forest and rural habitats of Poland compared to other European populations. Journal of Zoology, London 250: 495-50:5.

Goszczyński J. and Skoczyńska J. 1996. Density estimation, family group size and recruitment in a badger population near Rogów (Central Poland). Miscellánia Zoológica 19(2): 27-32.

Harris S. and Cresswell W. J. 1987. Dynamics of a suburban badger (Meles meles) population. Symposia of the Zoological Society of London 58 295-311.

Hofer H. 1988. Variation in resource presence, utilisation and reproductive success within a population of European badgers (Meles melles). Mammal Review 18: 25-36. 
Ivanter E. V. 1973. [Notes on an investigation of the badger near the northern limit of its range]. Trudy Gosudarstvennogo Zapovednika Kivach 2: 164-173. [In Russian]

Jenkinson S. and Wheater C. P. 1998. The influence of public access and sett visibility on badger (Meles meles) sett disturbance and persistence. Journal of Zoology, London 246: 478-482.

Jędrzejewska B. and Jędrzejewski W. 1998. Predation in vertebrate communities. The Białowieża Primeval Forest as a case study. Springer-Verlag, Berlin: 1-450.

Korochkina L. N., Kovonkov M. P. and Tolkach V. N. 1980. [Belovezha Primeval Forest]. Izdatelstvo Uradzhai, Minsk: 1-230. [In Russian]

Kruuk H. 1978. Spatial organization and territorial behaviour of the European badger Meles meles. Journal of Zoology, London 184: 1-19.

Kruuk H. and Parish T. 1982. Factors affecting population density, group size and territory size of the European badger, Meles meles. Journal of Zoology, London 196: 31-39.

Kruuk H., Parish T., Brown C. A. J. and Carrera J. 1979. The use of pasture by the European badger (Meles meles). Journal of Applied Ecology 16: 453-459.

Kwiatkowski W. 1994. Vegetation landscapes of Białowieża Forest. Phytocenosis 6: 35-87.

Likhachev G. N. 1956. [Some features of badger ecology in broad-leaved forests of the Tula region]. [In: Sbornik materialov po rezultatam izucheniya mlekopitayushchikh v gosudarstvennykh zapovednikakh. P. B. Yurgenson, ed]. Izdatelstvo Ministerstva Selskogo Khozyaistva SSSR, Moskva: 72-94. [In Russian]

Lobachev Yu. S. 1976. The ecology of Meles meles in the mountains of southern Kazakhstan. Byulleten Moskovskogo Obshchestva Ispytatelei Prirody, Otdel Biologicheskiï 81(5): 7-21. [In Russian with English summary]

Macdonald D. W., Mitchelmore F. and Bacon P. J. 1996. Predicting badger sett numbers: evaluating methods in East Sussex. Journal of Biogeography 23: 649-655.

Neal E. 1986. The natural history of badger. Croom Helm, Beckenham: 1-238.

O'Corry-Crowe G., Eves J. and Hayden T. J. 1993. Sett distribution, territory size and population density of badgers (Meles meles L.) in east Offaly. [In: The badger. T. J. Hayden, ed.]. Royal Irish Academy, Dublin: 35-56.

Ostler J. R. and Roper T. J. 1998. Changes in size, status, and distribution of badger Meles meles L. setts during a 20-year period. Zeitschrift für Säugetierkunde 63: 200-209.

Pelikan J. and Vackar J. 1978. Densities and fluctuation in numbers of red fox, badger, and pine marten in the Bučin Forest. Folia Zoologica 27: 289-303.

Priemer J. 1999. Untersuchungen an Rotfuchs- und Dachsbauen im storungsarmen Gebiet Lieberose. Beitrage zur Jagd- und Wildforschung 24: 355-367.

Quadrelli G. 1993. Density and distribution of badger's setts (Meles meles) in the Lower Lodigiano (Northern Italy). Natura Bresciana, Annali di Museo Civico di Storia Naturale 28: 429-431. [In Italian with English summary]

Rodriguez A., Martin R. and Delibes M. 1996. Space use and activity in a Mediterranean population of badgers Meles meles. Acta Theriologica 41: 59-72.

Rogers L. M., Cheeseman C. L. and Mallinson P. J. 1997. The demography of a high-density badger (Meles meles) population in the west of England. Journal of Zoology, London 242: 705-728.

Rusanov Ya. S. 1962. [Effect of fox control on the abundance of young generation in red deer and roe deer in Belovezha Primeval Forest]. Tezisy dokladov II zoologicheskoi konferencii BSSR, Minsk: 91-93. [In Russian]

Seiler A., Lindstrom E. and Stenstrom D. 1995. Badger abundance and activity in relation to fragmentation of foraging biotopes. Annales Zoologici Fennici 32: 37-45.

Shaparev Yu. P. 1977. [Distribution and numbers of the badger in forests of the lower part of the Angara river basin]. [In: Ekologiya i ispolzovanie okhotnichikh zhivotnykh Krasnoyarskogo kraya]. Akademiya Nauk SSSR, Sibirskoe Otdelenie, Institut Lesa i Drevesiny im. V. N. Sukacheva, Krasnoyarsk: 60-62. [In Russian] 
Stiebling U. and Schneider R. 1999. Zur Habitatnutzung des Rotfuchses Vulpes vulpes (L., 1758) in der uckermarkischen Agrarlandschaft: Ergebnisse zur Populations-dichte und -dynamik. Beitrage zur Jagd- und Wildforschung 24: 331-341.

Thornton P. S. 1988. Density and distribution of badgers in south-west England - a predictive model. Mammal Review 18: 11-23.

Ulevicius A. 1997. Burrowing carnivores in Žemaitija National Park, NW Lithuania: burrow setts and territory use. Acta Zoologica Lithuanica, Biodiversity 7: 127-132.

Utenkova A. P. and Nazarova N. S. 1968. [Distribution of earthworms in soils of Belovezha Primeval Forest]. Belovezhskaya Pushcha, Issledovaniya 2: 155-160. [In Russian]

Virgós E. and Casanovas J. G. 1999. Badger Meles meles sett site selection in low density Mediterranean areas of central Spain. Acta Theriologica 44: 173-182.

Wiertz J. and Vink J. 1986. The present status of the badger Meles meles (L., 1758) in the Netherlands. Lutra 29: 21-53,

Zoss A. 1992. Some aspects of the ecology of European badger (Meles meles L.) in the Slitere Nature Reserve. Acta et commentationes Universitatis Tartuensis 55: 176-185.

Received 18 January 2000, accepted 15 June 2000. 
Appendix I. Densities of main setts and individuals in badger populations in the Palaearctic region. a lower number are setts with litters recorded in 1997, higher number are setts with litters and all large setts constantly visited by badgers; ${ }^{b}$ all intensively occupied setts, including non-breeding ones; ${ }^{c}$ increase in the mean densities recorded between $1968-1978$ and 1988.

\begin{tabular}{|c|c|c|c|c|c|}
\hline Country, locality & $\begin{array}{c}\text { Latitude } \\
\text { and longitude }\end{array}$ & $\begin{array}{c}\text { Sett } \\
\text { density } \\
(n \text { setts/ } \\
\left.10 \mathrm{~km}^{2}\right)\end{array}$ & $\begin{array}{c}\text { Badger } \\
\text { density } \\
(n \text { ind/ } \\
\left.10 \mathrm{~km}^{2}\right)\end{array}$ & $\begin{array}{c}\text { Wood } \\
\text { cover } \\
(\%)\end{array}$ & Source \\
\hline 1 & 2 & 3 & 4 & 5 & 6 \\
\hline \multicolumn{6}{|c|}{ Continental Europe and Asia } \\
\hline $\begin{array}{l}\text { Czech Republic, Bučin } \\
\text { Forest }\end{array}$ & $49^{\circ} 13^{\prime} \mathrm{N}, 16^{\circ} 40^{\prime} \mathrm{E}$ & 1.8 & 9.8 & 100 & Pelikan and Vackar 1978 \\
\hline $\begin{array}{l}\text { Germany, } \\
\text { Schorfheide-Chorin }\end{array}$ & $53^{\circ} 06^{\prime} \mathrm{N}, 13^{\circ} 57^{\prime} \mathrm{E}$ & 2.2 & - & 0 & $\begin{array}{l}\text { Stiebling and Schneider } \\
1999\end{array}$ \\
\hline Germany, Lieberose & $52^{\circ} 10^{\prime} \mathrm{N}, 14^{\circ} 20^{\prime} \mathrm{E}$ & 2.4 & - & - & Priemer 1999 \\
\hline Italy, Northern Luino & $46^{\circ} \mathrm{N}, 8^{\circ} 44^{\prime} \mathrm{E}$ & 1.1 & - & 87 & Biancardi and Rinetti 1998 \\
\hline Italy, Basso Lodigiano & $45^{\circ} 13^{\prime} \mathrm{N}, 9^{\circ} 30^{\prime} \mathrm{E}$ & 2.0 & - & - & Quadrelli 1993 \\
\hline $\begin{array}{l}\text { Kazakhstan, Dzhungarskii } \\
\text { Alatau }\end{array}$ & $45^{\circ} 30^{\prime} \mathrm{N}, 80^{\circ} 30^{\prime} \mathrm{E}$ & 6.5 & 15.2 & 100 & Lobachev 1976 \\
\hline Latvia, Slitere Reserve & $57^{\circ} 40^{\prime} \mathrm{N}, 22^{\circ} 21^{\prime} \mathrm{E}$ & 1.1 & - & 70 & Zoss 1992 \\
\hline $\begin{array}{l}\text { Lithuania, Žemaitija } \\
\text { National Park }\end{array}$ & $56^{\circ} 05^{\prime} \mathrm{N}, 21^{\circ} 50^{\prime} \mathrm{E}$ & $0.2-0.5^{\mathrm{a}}$ & - & 36 & Ulevicius 1997 \\
\hline Norway, Malvik & $63^{\circ} 20^{\prime} \mathrm{N}, 10^{\circ} 45^{\prime} \mathrm{E}$ & 0.7 & - & 81 & Broseth et al. 1997 \\
\hline Poland, Rogów & $51^{\circ} 48^{\prime} \mathrm{N}, 19^{\circ} 53^{\prime} \mathrm{E}$ & 1.1 & 3.1 & 17 & $\begin{array}{l}\text { Goszczyński and } \\
\text { Skoczyńska } 1996\end{array}$ \\
\hline Poland, Suwałki & $54^{\circ} 17^{\prime} \mathrm{N}, 22^{\circ} 52^{\prime} \mathrm{E}$ & 1.0 & 5.9 & 24 & Goszczyński 1999 \\
\hline Poland, Białowieża Forest & $52^{\circ} 41^{\prime} \mathrm{N}, 23^{\circ} 50^{\prime} \mathrm{E}$ & 0.4 & 1.6 & 100 & This study \\
\hline Russia, Kivach Reserve & $62^{\circ} 15^{\prime} \mathrm{N}, 34^{\circ} 12^{\prime} \mathrm{E}$ & 1.2 & $4.3-4.9$ & 100 & Ivanter 1973 \\
\hline Russia, Motygino & $58^{\circ} 15^{\prime} \mathrm{N}, 94^{\circ} 43^{\prime} \mathrm{E}$ & $\leq 2.3^{\mathrm{b}}$ & - & 100 & Shaparev 1977 \\
\hline Russia, Tula Forest & $54^{\circ} 55^{\prime} \mathrm{N}, 36^{\circ} 58^{\prime} \mathrm{E}$ & 2.3 & - & 100 & Likhachev 1956 \\
\hline Spain, Doñana Natl. Park & $37^{\circ} \mathrm{N}, 6^{\circ} 30^{\prime} \mathrm{W}$ & 1.6 & 3.6 & 15 & Rodriguez et al. 1996 \\
\hline Spain, Alto Manzanares & $41^{\circ} 40^{\prime} \mathrm{N}, 4^{\circ} 10^{\prime} \mathrm{E}$ & 0.4 & - & 61 & Virgós and Casanovas 1999 \\
\hline \multicolumn{6}{|c|}{ British Isles } \\
\hline England, Avon & $51^{\circ} 27^{\prime} \mathrm{N}, 2^{\circ} 35^{\prime} \mathrm{W}$ & 10.1 & 58.0 & 7 & Cheeseman et al. 1981 \\
\hline England, Bradford & $53^{\circ} 48^{\prime} \mathrm{N}, 1^{\circ} 45^{\prime} \mathrm{W}$ & 1.1 & - & 0 & $\begin{array}{l}\text { Jenkinson and Wheater } \\
1998\end{array}$ \\
\hline England, Bristol City & $51^{\circ} 27^{\prime} \mathrm{N}, 2^{\circ} 35^{\prime} \mathrm{W}$ & - & $44.0-75.0$ & 0 & Cresswell and Harris 1988 \\
\hline England, Cornwall & $50^{\circ} 30^{\prime} \mathrm{N}, 5^{\circ} \mathrm{W}$ & 13.5 & 65.0 & 6 & Cheeseman et al. 1981 \\
\hline England, East Sussex & $50^{\circ} 55^{\prime} \mathrm{N}, 1^{\circ} 45^{\prime} \mathrm{W}$ & $4.8-5.8^{c}$ & $28.8-34.8$ & - & Macdonald et al. 1996 \\
\hline England, Gloucestershire 1 & $51^{\circ} 53^{\prime} \mathrm{N}, 2^{\circ} 14^{\prime} \mathrm{W}$ & 45.5 & 220.0 & 20 & Cheeseman et al. 1981 \\
\hline England, Gloucestershire 2 & $51^{\circ} 53^{\prime} \mathrm{N}, 2^{\circ} 14^{\prime} \mathrm{W}$ & 40.3 & 307.0 & 20 & Cheeseman et al. 1981 \\
\hline England, South Downs & $50^{\circ} 52^{\prime} \mathrm{N}, 0^{\circ} 01^{\prime} \mathrm{E}$ & 31.2 & 190.0 & 0 & Ostler and Roper 1998 \\
\hline England, Stafford & $52^{\circ} 48^{\prime} \mathrm{N}, 2^{\circ} 07^{\prime} \mathrm{W}$ & 9.6 & 86.4 & 15 & Cheeseman et al. 1985 \\
\hline England, Woodchester Park & $51^{\circ} 44^{\prime} \mathrm{N}, 2^{\circ} 16^{\prime} \mathrm{W}$ & 28.8 & 253.0 & 23 & Rogers et al. 1997 \\
\hline England, Wytham Wood & $51^{\circ} 46^{\prime} \mathrm{N}, 1^{\circ} 18^{\prime} \mathrm{W}$ & 9.3 & 34.8 & 36 & Hofer 1988 \\
\hline
\end{tabular}


Appendix 1 - concluded.

\begin{tabular}{|c|c|c|c|c|c|}
\hline 1 & 2 & 3 & 4 & 5 & 6 \\
\hline Ireland, Castleward & $54^{\circ} 23^{\prime} \mathrm{N}, 5^{\circ} 35^{\prime} \mathrm{W}$ & 22.7 & 119.0 & 29 & $\begin{array}{l}\text { Feore and Montgomery } \\
1999\end{array}$ \\
\hline Ireland, Glenwhirry & $54^{\circ} 40^{\prime} \mathrm{N}, 6^{\circ} 10^{\prime} \mathrm{W}$ & 3.4 & 8.6 & 5 & $\begin{array}{l}\text { Feore and Montgomery } \\
1999\end{array}$ \\
\hline Ireland, Katesbridge & $54^{\circ} 18^{\prime} \mathrm{N}, 6^{\circ} 08^{\prime} \mathrm{W}$ & 7.9 & 16.0 & 2 & $\begin{array}{l}\text { Feore and Montgomery } \\
1999\end{array}$ \\
\hline Ireland, Offaly & $53^{\circ} 14^{\prime} \mathrm{N}, 7^{\circ} 19^{\prime} \mathrm{W}$ & 6.5 & 44.0 & 7 & O'Corry-Crowe et al. 1993 \\
\hline Scotland, Ardnish & $56^{\circ} 55^{\prime} \mathrm{N}, 5^{\circ} 51^{\prime} \mathrm{W}$ & 5.8 & 20.3 & 0 & Kruuk and Parish 1982 \\
\hline Scotland, Aviemore & $57^{\circ} 12^{\prime} \mathrm{N}, 3^{\circ} 50^{\prime} \mathrm{W}$ & 6.7 & 22.0 & 50 & Kruuk and Parish 1982 \\
\hline Scotland, New Deer & $57^{\circ} 31^{\prime} \mathrm{N}, 2^{\circ} 11^{\prime} \mathrm{W}$ & 6.3 & 59.9 & 0 & Kruuk and Parish 1982 \\
\hline
\end{tabular}

